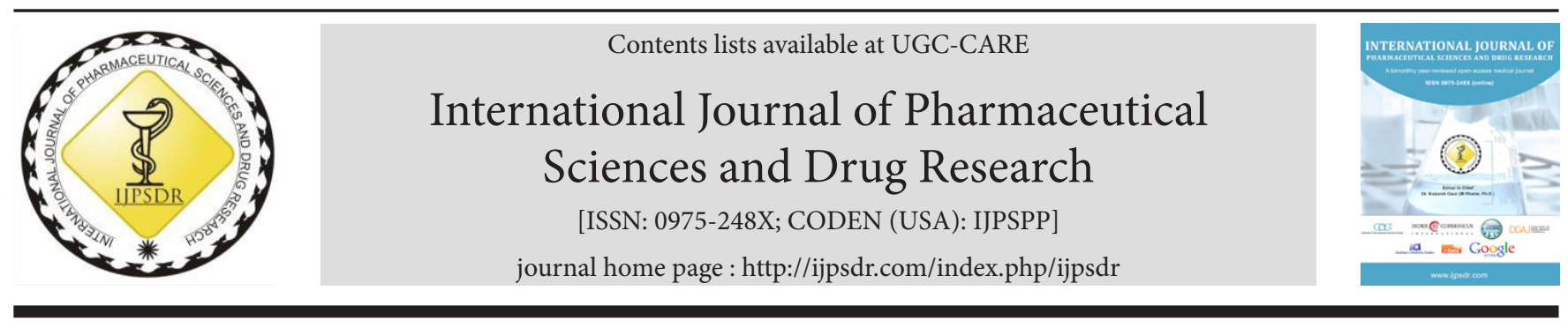

Research Article

\title{
Phytochemical Analysis and In vitro Anti Obesity Activity of Different Fractions of Methanolic Extract of Fagonia cretica L.
}

\author{
Divyang Patel ${ }^{1 *}$, Vimal Kumar ${ }^{2}$ \\ ${ }^{1}$ Department of Pharmacognosy, Institute of Pharmacy, Nirma University, S. G. Highway, Ahmedabad-382481, Gujarat, India \\ ${ }^{2}$ ITM School of Pharmacy, ITM (SLS) Baroda University, Dhanora Tank Road, Village-Paldi, Nr. Jarod, Tal-Waghodia, Vadodara-391510, Gujarat, India
}

\begin{tabular}{l} 
A R T I C L E I N F O \\
\hline Article history: \\
Received: 24 March, 2020 \\
Revised: 27 April, 2020 \\
Accepted: 02 May, 2020 \\
Published: 30 May, 2020 \\
Keywords: \\
a amylase, \\
Fagonia cretica L., \\
Obesity, \\
Pancreatic lipase. \\
DOI: \\
10.25004/IJPSDR.2020.120311
\end{tabular}

\begin{abstract}
A B S T RAC T
Obesity is one of the most prevalent health concerns among all age groups and populations worldwide, resulting in a significant increase in mortality and morbidity related to metabolic disorders. Targeting one or more enzymes involved in lipid metabolism can be selective for evaluation of anti-obesity action of drug. The present study was aimed to evaluate in vitro anti-obesity action by inhibiting pancreatic lipase and $\alpha$ amylase enzyme by various fractions of methanolic extract of aerial parts Fagonia cretica $\mathrm{L}$. along with their phytochemical analysis. The n-hexane (HFFC), chloroform (CFFC), ethyl acetate (EAFFC), n-butanol (BFFC), and aqueous fractions (AQFFC) were prepared from methanolic extracts of $F$. cretica $\mathrm{L}$, and were analyzed for qualitative, as well as, quantitative phytochemical study using reported methods. The qualitative phytochemical studies of prepared extract and fractions showed presence of flavonoids, saponins, phenolics, alkaloids, and carbohydrates. All the fractions were then examined for their in vitro lipase inhibitory and $\alpha$ amylase inhibitory activities at a concentration level of 50,100, 150, and $200 \mu \mathrm{g} / \mathrm{mL}$, and their percentage inhibitory effects were reported. Among the analyzed samples, BFFC showed highest lipase inhibitory action, i.e., $83.02 \pm 2.47 \%$, as compared to other fractions. EAFFC showed significantly higher $\alpha$ amylase inhibitory action, i.e., $80.22 \pm 1.18 \%$ as compared to other fractions.
\end{abstract}

\section{INTRODUCTION}

Obesity is one of the non-communicable lifestyle disorders characterized by excess adipose tissue mass with body mass index (BMI) $>25 \mathrm{~kg} / \mathrm{m}^{2}{ }^{[1]}$ It can be considered as a cosmetic problem associated with various other lifestyle disorders, like diabetes, dyslipidemia, hypertension, cardiovascular diseases, musculoskeletal disorders, cancer, etc. Change in lifestyle along with regular exercise for obesity treatment is less effective for long term weight loss. Targeting the inhibition of one or more enzymes involved in lipid and carbohydrate metabolism is the best option for evaluation of anti-obesity action of drugs. Absorption of dietary triglycerides in small intestine involves their hydrolysis into free fatty acids by pancreatic lipase enzyme. ${ }^{[2]}$ On the other side, absorption of carbohydrates in small intestine involves their hydrolysis into simple sugars by amylase enzymes. Inhibition of these enzymes could be beneficial in weight control and weight loss treatments.

F. cretica L. (family: Zygophyllaceae) is a short erect spiny undershrub with slender branches, terete striates, a glabrous or sparsely glandular puberulous growing almost throughout the year majorly in north-west India. ${ }^{[3]}$ The plant is used as a bitter tonic, diuretic, astringent, and prophylactic against smallpox. It is also used for the treatment of dysentery, asthma, fever, thirst, vomiting, urinary discharges, liver trouble, dyslipidemia, typhoid, toothache, stomach troubles, and skin diseases. ${ }^{[4,5]}$ Research reports available on F. cretica L. showed presence of alkaloids, saponins, flavonoids, phenolics, tannins, and vitamins in whole plant. ${ }^{[6]}$ A number of in vivo and/ or in vitro studies have explained a wide spectrum of pharmacological properties of crude extracts of

\footnotetext{
${ }^{*}$ Corresponding Author: Divyang Patel

Address: Department of Pharmacognosy, Institute of Pharmacy, Nirma University, S. G. Highway, Ahmedabad-382481, Gujarat, India

Email $₫$ : divspatel87@gmail.com

Relevant conflicts of interest/financial disclosures: The authors declare that the research was conducted in the absence of any commercial or financial relationships that could be construed as a potential conflict of interest.

Copyright (c) 2020 Divyang Patel et al. This is an open access article distributed under the terms of the Creative Commons Attribution- NonCommercialShareAlike 4.0 International License which allows others to remix, tweak, and build upon the work non-commercially, as long as the author is credited and the new creations are licensed under the identical terms.
} 
plant, including anticancer, ${ }^{[7,8]}$ anti-inflammatory, analgesic, ${ }^{[9]}$ anti-microbial, ${ }^{[10]}$ immunomodulatory, ${ }^{[11]}$ hepatoprotective, ${ }^{[12]}$ and antioxidant. ${ }^{[13]}$ In Ayurvedic literature, this plant is mentioned for fat reduction property, ${ }^{[14]}$ but to date, there is no scientific evidence available proving this claim. Therefore, the present study was designed to investigate in vitro anti-obesity action of different fractions of methanolic extracts of $F$. cretica $\mathrm{L}$. by using lipase inhibitory and amylase inhibitory assays by reported methods.

\section{MATERIALS AND METHODS}

\section{Collection and Identification of Plant Material}

Drug sample of F. cretica L. was procured from local market of Vadodara, Gujarat, India, in the month of June 2015. The drug sample was identified by comparing its morphological characters described in various standard texts. ${ }^{[14]}$ It was further authenticated by botanist Dr. P K Patel, Head of Department, Sheth P. T. Arts and Science College, Godhra, Gujarat bearing voucher specimen number PPDC/COG/2015/001 as F. cretica L. belongs to the family Zygophyllaceae. It was dried under sunlight for 2 days to minimize moisture content and then powdered, and the powder sample was passed through 60\# sieve and stored in an airtight container at room temperature for further use.

\section{Extraction and Fractionation}

Powdered aerial parts of $F$. cretica L. (1 kg) were extracted with methanol $(2.5 \mathrm{~L})$ by maceration method at room temperature for 7 days, followed by filtration using filter paper. Dried marc was again extracted with methanol (2.5 L) by same method for 7 days. Two percolates were mixed, concentrated and evaporated to dryness to give methanolic extracts of Fagonia cretica (MEFC) (yield: $4.87 \% \mathrm{w} / \mathrm{w}$ ). The dried extract was suspended in water $(250 \mathrm{~mL})$, and subsequently extracted with n-hexane, chloroform, ethyl acetate, and n-butanol $(250 \mathrm{~mL}$ each) by liquid-liquid partition in separating funnel with respective solvent. All solvent fractions were evaporated to dryness under reduced pressure and designated as HFFC $(0.59 \% \mathrm{w} / \mathrm{w}), \mathrm{CFFC}(0.67 \% \mathrm{w} / \mathrm{w}), \operatorname{EAFFC}(0.53 \% \mathrm{w} / \mathrm{w})$, $\mathrm{BFFC}(0.82 \% \mathrm{w} / \mathrm{w})$, and remaining AQFFC $(1.69 \% \mathrm{w} / \mathrm{w})$.

\section{Preliminary Phytochemical Screening and Quantitative Estimation of Phytoconstituents}

Preliminary phytochemical screening of methanolic extracts, along with all the fractions, was performed using standard reported procedures for the detection of various secondary metabolites. ${ }^{[15-17]}$ Total flavonoids and saponins contents of EAFFC and BFFC were determined by using standard reported methods. ${ }^{[18,19]}$

\section{In vitro Lipase Inhibitory Activity}

Lipase inhibitory activity of prepared fractions of methanolic extracts of $F$. cretica L. was determined by using a method described by Etoundi CB et al. ${ }^{[20]}$ The rate of release of oleic acid from triolein was determined for measuring lipase inhibitory action. A suspension containing $1 \%(\mathrm{v} / \mathrm{v})$ of triolein, and $1 \%(\mathrm{v} / \mathrm{v})$ tween 40 in $0.1 \mathrm{M}$ phosphate buffer $(\mathrm{pH} 8)$ was prepared and emulsified. Porcine pancreatic lipase $(0.5 \mathrm{gm})$ was dissolved in $15 \mathrm{~mL} 0.1 \mathrm{M}$ phosphate buffer ( $\mathrm{pH}$ 8). $800 \mu \mathrm{L}$ of the triolein emulsion was added to $200 \mu \mathrm{L}$ of porcine pancreatic lipase and to those different concentrations of fractions of methanolic extracts $(50,100,150$, and $200 \mu \mathrm{g} / \mathrm{mL}$ ) were added. Orlistat, a potent pancreatic lipase inhibitor was taken as reference standard drug. Immediately after mixing the contents the absorbance was measured at $450 \mathrm{~nm}$ and designated as $\mathrm{T}_{1}$. The test tubes were incubated at $37^{\circ} \mathrm{C}$ for 30 minutes, and at the end of the incubation, the absorbance at $450 \mathrm{~nm}$ was recorded and designated as $\mathrm{T}_{2}$.

The variation in absorbance $=\left[\mathrm{A} 450\left(\mathrm{~T}_{1}\right)-\mathrm{A} 450\left(\mathrm{~T}_{2}\right)\right]$ was calculated for both control and the treatment, and the $\%$ inhibition was calculated using the formula:

$\%$ inhibition $=[(\Delta \mathrm{A} 450$ control $-\Delta \mathrm{A} 450$ extract $) / \Delta \mathrm{A} 450$ control] $\times 100$

\section{In vitro $\mathbf{\alpha}$-Amylase Inhibitory Activity ${ }^{[21]}$}

Soluble starch (500 mg) was dissolved in $25 \mathrm{~mL}$ of $0.4 \mathrm{M}$ $\mathrm{NaOH}$ and heated for 5 minutes at $100^{\circ} \mathrm{C}$. The $\mathrm{pH}$ of solution was adjusted to 7 with $2 \mathrm{M} \mathrm{HCl}$ cooling in ice $\mathrm{H}_{2} \mathrm{O}$, and water was added to adjust the volume to $100 \mathrm{~mL}$. The substrate $(40 \mu \mathrm{L})$ and fractions $(20 \mu \mathrm{L})$ solutions (50, 100,150 , and $200 \mu \mathrm{g} / \mathrm{mL}$ ) were mixed in a microplate well, and the mixtures were pre-incubated at $37^{\circ} \mathrm{C}$ for 3 minutes, followed by addition of $20 \mu \mathrm{L}$ of $\alpha$-amylase solution $(50 \mu \mathrm{g} / \mathrm{mL})$ to each well, and incubation of plate for 15 minutes. At last $80 \mu \mathrm{L}$ of $0.1 \mathrm{M} \mathrm{HCl}$ and $200 \mu \mathrm{L}$ of 1 $\mathrm{mM}$ iodine solution were added to terminate the reaction. Acarbose, a potent $\alpha$-amylase inhibitor, was selected as reference standard drug. The absorbance (Abs) was measured at $650 \mathrm{~nm}$.

Inhibitory activity was calculated as follows:

$$
\begin{aligned}
& \text { Inhibition (\%) }=[1-(\text { Abs } 2-A b s 1) /(A b s 4-A b s 3) \times \\
& \text { 100] }
\end{aligned}
$$

Where, Abs 1 is the absorbance of incubated solution containing fractions, starch, and amylase; Abs 2 is the absorbance of incubated solution containing fractions and starch; Abs 3 is the absorbance of incubated solution containing starch and amylase; Abs 4 is the absorbance of incubated solution containing starch.

\section{Data Analysis}

All the experimental results were expressed as mean \pm standard error mean (SEM) of three parallel measurements. The $\mathrm{IC}_{50}$ values of all test samples were calculated from concentration-inhibition curves. Statistical significance of differences between means was calculated by analysis of variance (ANOVA), followed 
Phytochemical Analysis and In vitro Anti Obesity Activity of Fagonia cretica L.

Table 1: Preliminary phytochemical screening of methanolic extracts and different fractions of Fagonia cretica L.

\begin{tabular}{|c|c|c|c|c|c|c|}
\hline \multirow[b]{2}{*}{ Phytoconstituent } & \multicolumn{6}{|c|}{ Extract and fractions } \\
\hline & $M E F C$ & $H F F C$ & CFFC & EAFFC & $B F F C$ & $A Q F F C$ \\
\hline Flavonoids & + & - & - & + & + & + \\
\hline Saponins & + & - & + & + & + & + \\
\hline Phenolics & + & - & - & + & + & + \\
\hline Alkaloids & + & - & + & + & - & - \\
\hline Terpenoids & + & + & - & + & - & - \\
\hline Anthraquinone glycosides & - & - & - & - & - & - \\
\hline Cardiac glycosides & + & - & - & + & - & + \\
\hline Carbohydrates & + & - & - & - & + & + \\
\hline
\end{tabular}

+ = present; - = absent

Table 2: Effects of different concentrations of various fractions of methanolic extracts of Fagonia cretica L. on pancreatic lipase activity

\begin{tabular}{lll}
\hline Test sample & Concentration $(\mu \mathrm{g} / \mathrm{mL})$ & Inhibition $(\%)^{*}$ \\
\hline HFFC & 50 & $12.34 \pm 0.32$ \\
& 100 & $14.76 \pm 1.16$ \\
& 150 & $16.12 \pm 0.65$ \\
CFFC & 200 & $20.33 \pm 0.42$ \\
& 50 & $23.12 \pm 0.87$ \\
& 100 & $29.33 \pm 1.34$ \\
EAFFC & 150 & $32.45 \pm 2.41$ \\
& 200 & $34.72 \pm 1.32$ \\
& 100 & $27.62 \pm 1.75$ \\
BFFFC & 150 & $34.26 \pm 1.43$ \\
& 200 & $41.17 \pm 0.22$ \\
& 50 & $48.22 \pm 1.74$ \\
AQFFC & 100 & $43.32 \pm 2.37$ \\
& 150 & $57.76 \pm 1.56$ \\
& 100 & $72.33 \pm 0.28$ \\
& 150 & $83.02 \pm 2.47$ \\
Orlistat & 50 & $5.23 \pm 0.41$ \\
& 100 & $7.76 \pm 1.76$ \\
& 150 & $11.87 \pm 1.82$ \\
& 200 & $13.45 \pm 2.16$ \\
& 500 & $64.22 \pm 1.45$ \\
& $100.87 \pm 2.25$ \\
& 100 & $88.23 \pm 1.63$ \\
& & $92.54 \pm 3.36$ \\
\hline
\end{tabular}

${ }^{*} \mathrm{n}=3$; values are represented as mean \pm SEM

by Dunnett's multiple comparisons test. $\mathrm{p}<0.05$ was considered statistically significant.

\section{RESULTS}

\section{Preliminary Phytochemical Screening and Quantitative Estimation of Phytoconstituents}

Different chemical tests were performed to detect presence of different classes of phytoconstituents. Results of the preliminary phytochemical screening of methanolic extracts and prepared fractions are shown in Table 1. The qualitative phytochemical studies of prepared extract and fractions showed the presence of flavonoids,

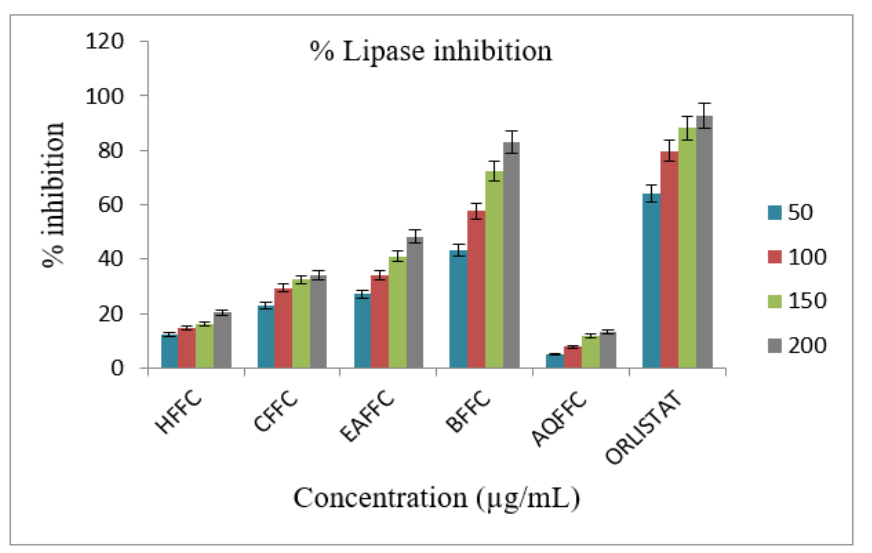

Fig. 1: \% lipase inhibition of different fractions of MEFC

saponins, phenolics, alkaloids, and carbohydrates. The total flavonoid content of EAFFC and BFFC was found to be $12.28 \pm 0.37 \mathrm{mg}$ and $2.43 \pm 0.83 \mathrm{mg}$ of quercetin equivalents/grams of fraction, respectively. Total saponin content of EAFFC and BFFC was found to be $9.76 \pm 0.33 \mathrm{mg}$ and $36.12 \pm 1.04 \mathrm{mg}$ of diosgenin equivalent/grams of fraction, respectively.

\section{In vitro Lipase Inhibitory Activity}

In the present study, in vitro lipase inhibitory effect of different fractions of methanolic extracts of $F$. cretica $\mathrm{L}$. was evaluated using rate of release of oleic acid from triolein. Results of \% lipase inhibitory activity of all fractions and standard drug orlistat are shown in Table 2. The present findings revealed statistically significant $(\mathrm{p}<0.05)$ lipase inhibitory action of BFFC and standard drug orlistat as compared to other fractions (Fig. 1). $\mathrm{IC}_{50}$ value of BFFC was found to be $72.32 \pm 0.52 \mu \mathrm{g} / \mathrm{mL}$, which was comparable with standard drug orlistat having $\mathrm{IC}_{50}$ value $42.36 \pm 1.43 \mu \mathrm{g} / \mathrm{mL}$ (Fig. 2).

\section{In vitro $\alpha$-Amylase Inhibitory Activity}

Results of \% $\alpha$-amylase inhibitory of all fractions and standard drug acarbose are shown in Table 3. The present studies state statistically significant $(\mathrm{p}<0.05) \alpha$-amylase inhibitory action of EAFFC and standard drug acarbose as compared to other fractions (Fig. 3). $\mathrm{IC}_{50}$ value of 


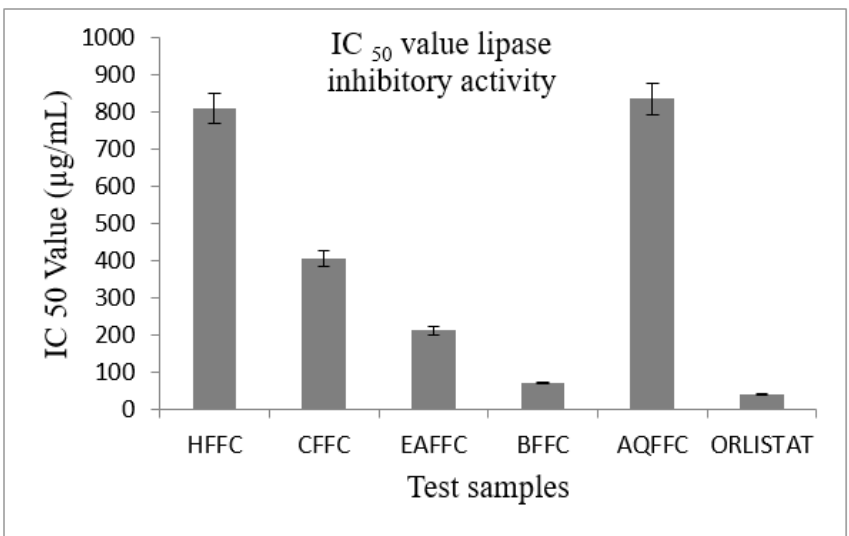

Fig. 2: $\mathrm{IC}_{50}$ values of different fractions MEFC for lipase inhibitory activity

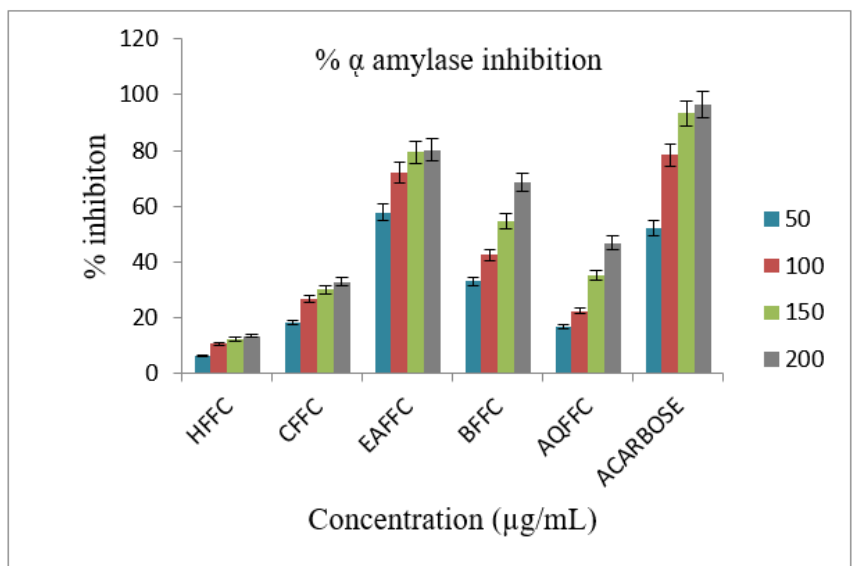

Fig. 3: \% $\alpha$ amylase inhibition of different fractions of MEFC

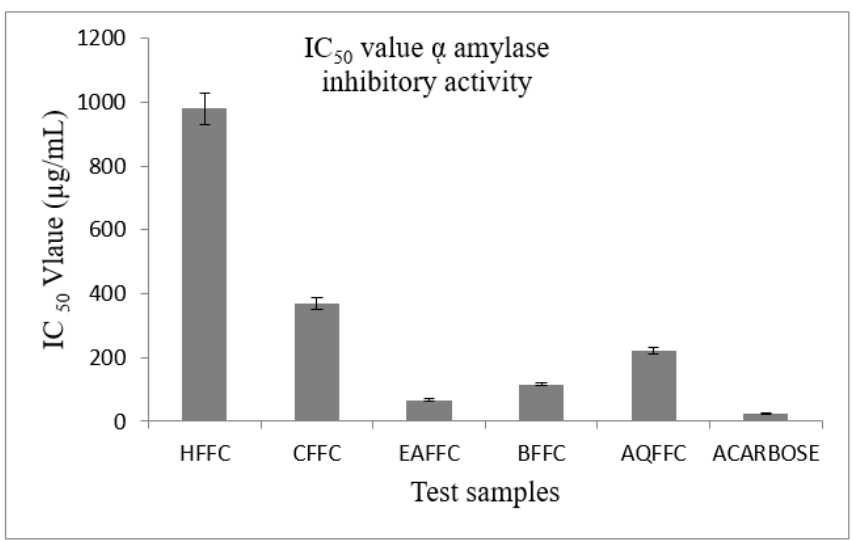

Fig. 4: $\mathrm{IC}_{50}$ values of different fractions MEFC for $\underset{\iota}{\alpha}$ amylase inhibitory activity

EAFFC was found to be $66.52 \pm 2.48 \mu \mathrm{g} / \mathrm{mL}$, which was comparable with standard drug acarbose having $\mathrm{IC}_{50}$ value $23.35 \pm 0.23$ (Fig. 4).

\section{Discussion}

Obesity is now dramatically on the rise in low- and middleincome countries, particularly in urban settings. It is now considered a chronic disease that is reaching epidemic proportions in the developed world. ${ }^{[22]}$ Development of
Table 3: Effects of different concentrations of various fractions of methanolic extracts of Fagonia cretica L. on $\alpha$-amylase activity

\begin{tabular}{lll}
\hline Test sample & Concentration $(\mu \mathrm{g} / \mathrm{mL})$ & Inhibition $(\%)^{*}$ \\
\hline HFFC & 50 & $6.34 \pm 0.09$ \\
& 100 & $10.76 \pm 0.56$ \\
& 150 & $12.32 \pm 0.31$ \\
CFFC & 200 & $13.58 \pm 1.98$ \\
& 50 & $18.41 \pm 0.49$ \\
& 100 & $26.89 \pm 1.52$ \\
EAFFC & 150 & $30.24 \pm 1.83$ \\
& 200 & $32.98 \pm 2.46$ \\
& 50 & $57.88 \pm 2.54$ \\
BFFFC & 100 & $72.15 \pm 2.69$ \\
& 150 & $79.44 \pm 1.66$ \\
& 200 & $80.22 \pm 1.18$ \\
& 100 & $33.06 \pm 1.03$ \\
AQFFC & 150 & $42.56 \pm 1.51$ \\
& 200 & $54.57 \pm 0.94$ \\
& 50 & $68.56 \pm 1.24$ \\
& 100 & $16.76 \pm 0.31$ \\
Acarbose & 150 & $22.47 \pm 1.72$ \\
& 200 & $35.06 \pm 1.91$ \\
& 50 & $46.88 \pm 1.06$ \\
& 100 & $52.17 \pm 2.56$ \\
& 150 & $78.42 \pm 1.16$ \\
& 200 & $93.23 \pm 0.77$ \\
& $100.54 \pm 1.72$ \\
\hline
\end{tabular}

${ }^{*} \mathrm{n}=3$; values are represented as mean \pm SEM

nutrient digestion and absorption inhibitors is one of the most important strategy in the treatment of obesity. Inhibition of digestive enzymes is one of the most widely studied mechanisms used to determine the potential efficacy of natural products as anti-obesity agents. In present study, the methanolic extracts were prepared by using the maceration method of extraction. Fractionation of prepared methanolic extracts was done to separate different classes of phytoconstituents as per their solubility in different solvents. Preliminary phytochemical screening showed the presence of flavonoids, saponins, phenolics, alkaloids, and carbohydrates in different fractions, while anthraquinone and cardiac glycosides were found absent. Quantitative estimation of BFFC and EAFFC showed higher contents of saponins (36.12 $\pm 1.04 \mathrm{mg} / \mathrm{gm})$ and flavonoids $(12.28 \pm 0.37 \mathrm{mg} / \mathrm{gm})$, respectively. BFFC showed highest $(83.02 \pm 2.47 \%)$ inhibition of pancreatic lipase with $\mathrm{IC}_{50}$ value of $72.32 \pm 0.52 \mu \mathrm{g} / \mathrm{mL}$. EAFFC showed highest $(80.22 \pm 1.18 \%)$ inhibition of $\alpha$ amylase with $\mathrm{IC}_{50}$ value of $66.52 \pm 2.48 \mu \mathrm{g} / \mathrm{mL}$. The higher $\%$ inhibition of pancreatic lipase by BFFC and $\alpha$ amylase by EAFFC is attributed to the higher saponins and flavonoids contents, respectively, as determined by quantitative phytochemical analysis. Any prior report on in vitro anti-obesity activity of methanolic extracts and all different fractions of this plant has not been reported so far. The present study provided valuable preliminary data through demonstration of its probable use in weight loss therapy. 


\section{ACKNOWLEDGEMENT}

The authors would like to acknowledge Nirma University, Ahmedabad for the Guidance and support provided for the study.

\section{REFERENCES}

1. Hu FB, Li TY, Colditz GA, Willett WC, Manson JE. Television watching and other sedentary behaviors in relation to risk of obesity and type 2 diabetes mellitus in women. J of American Med Assoc. 2003;289:1785-1791.

2. Verger R. Interfacial activation of lipases: facts and antifacts. Trends in Biosciences. 1997;15:32-37.

3. Trivedi PC. Medicinal Plants Utilization and Conservation. Edn 2, Vol.1, Aavishkar Publication, Jaipur, 2009. p. 260.

4. Baquar SR. Medicinal and Poisonous Plants of Pakistan. Printas. Karachi;1989. p. 198-199.

5. Meyer BN, Ferrrigni NR, Putnam JE. Brine shrimp: a convenient general bioassay for active plant constituents. Planta Med. 1982;45:31-34.

6. Hussain I, Ullah R, Ullah R, Khurram M, Ullah N, Baseer A, et al. Phytochemical analysis of selected medicinal plants. Afr J Biotech. 2011;10:7487-7492.

7. Hussain A, Zia M, Mirza B. Cytotoxic and antitumor potential of Fagonia cretica L. Turk J Biol. 2007;31:19-24.

8. Lam M, Carmichael AR, Griffiths HR. An aqueous extract of Fagonia cretica induces DNA damage, cell cycle arrest and apoptosis in breast cancer cells via FOX03a and p53 expression. Plos one. 2012;7:6.

9. Sharma S, Joseph L, George M, Gupta V. Analgesic and antimicrobial activity of Fagonia indica. Pharmacology online. 2009;3: 623-632.

10. Anjum MI, Ahmed E, Jabbar A, Malik A, Ashraf M, Moazzam M.
Antimicrobial constituents from Fagonia cretica. J of Chem Soc of Pakistan. 2007;6:634-639.

11. Abhirami V, Khosa RL, Dhar SK, Sahai M. Investigation on Fagonia cretica-Its effect on hormonal profile and immunomodulation in rats. Ancient Science of Life. 1996;15(4):259-263.

12. Eldin HS, Gadir HA, Hassan AW. Evaluation of the hepatoprotective activity of Fagonia cretica L, Res. and Rew. J of Pharmacog and Phytochem. 2015;3:1-6.

13. Ali SS, Kasoju N, Luthra A, Singh A, Hallihosur S, Shahu A. Indian Medicinal plants as source of antioxidants. Food Res. Int. 2008;41:1-15.

14. Ayurvedic Pharmacopoeia of India. Part I, Edn 1, Vol. 5, Ministry of Health and Family Welfare, Department of Health, New Delhi, 2001. p. 30.

15. Harborne JB. Phytochemical methods: a guide to modern techniques of plant analysis. Chapman and Hall:London;1998. p. 34-86.

16. Trease GE, Evans WC. Pharmacognosy. Edn 11. London: Brailliar Tiridel Can Macmillan Publishers; 1989. p. 60-75.

17. Shah BN, Nayak BS. Experimental Pharmacognosy. Edn 1. S.Vikas and Company, Jalandhar;2008. p. 190-200.

18. Zhishen J, Mengcheng T, Jianming W. The determination of flavonoid contents in mulberry and their scavenging effects on superoxide radicals. Food Chem. 1999;64:555-559.

19. Obadoni B, Ochuko P. Phytochemical studies and comparative efficacy of the crude extracts of some haemostatic plants in edo and delta states of Nigeria. Global J of Pure and Applied Sci. 2002;8:203-208.

20. Etoundi CB, Kuaté D, Ngondi JL, Oben J. Anti-amylase, anti-lipase and antioxidant effects of aqueous extracts of some Cameroonian spices. J of Nat Prod. 2010;3:165-171.

21. Xiao Z, Storms R, Tsang A. A quantitative starch-iodine method for measuring alpha amylase and glucoamylase activities. Anal Biochem. 2006;351:146-148.

22. Rang HP, Dale MM, Ritter JM, Moore PK. Pharmacology. 5th ed. New Delhi: Elsevier; 2003. p. 410-419. 